(1) Renaissance Quarterly

The Renaissance Society of America

The Graduate School and University Center

The City University of New York 


\section{Renaissance Literature}

FROM CHICAGO

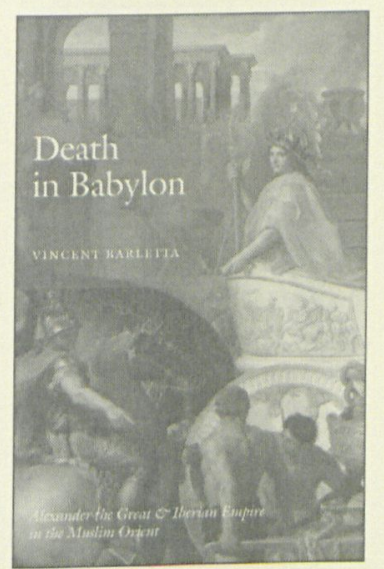

\section{Death in Babylon}

Alexander the Great and Iberian

Empire in the Muslim Orient

\section{Vincent Barletta}

"Learned and probing, Barletta's elegant monograph is a model of interpretive scholarship on the literary history of early modern Iberia: a profound meditation on imperial dreams and their cultural tropes under the lengthy shadow of Alexander the Great."

Luis M. Girón-Negrón, Harvard University CLOTH $\$ 45.00$

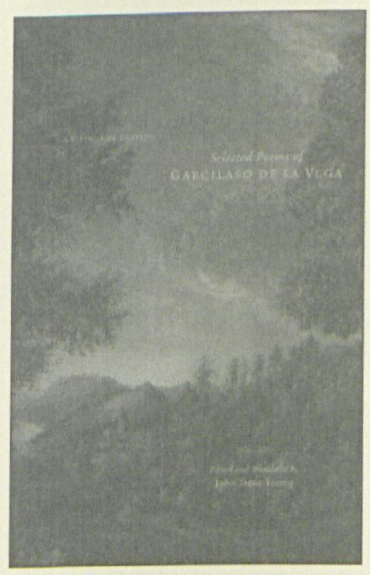

\section{Selected Poems of Garcilaso de la Vega}

A Bilingual Edition

\section{Edited and Translated by John Dent-Young}

"John Dent-Young has done something that I did not think possible: he has successfully rendered Garcilaso's verse in English in ways that capture its rhythm and grace, while at the same time conveying its sense with all the directness and elusiveness of the original."

Ricardo Padrón, University of Virginia

CLOTH $\$ 39.00$

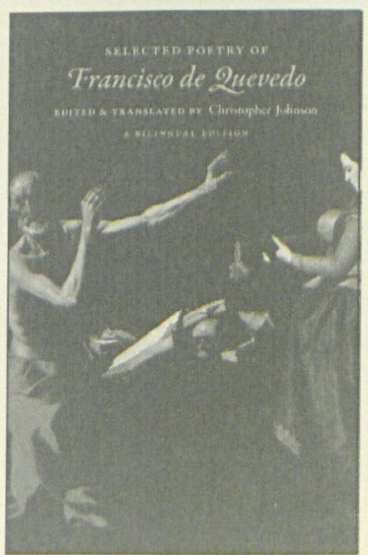

\section{Selected Poetry of Francisco de Quevedo}

A Bilingual Edition

\section{Francisco de Quevedo}

Edited and Translated by Christopher Johnson

"Francisco de Quevedo is considered today the major poet of the Spanish baroque, even surpassing in popularity the works of Góngora. . . . I very much appreciate the loving care that has gone into these renderings since they reveal the pessimism, the lyrical beauty, the burlesque vulgarities, the majestic complexities, and the daunting word-plays found in the original."

Frederick de Armas, University of Chicago CLOTH $\$ 45.00$

The University of Chicago Press - www.press.uchicago.edu 